UDC 616.98: 578.835.1

DOI: $10.21668 /$ health.risk/2021.3.10.eng

Research article

\title{
NEW APPROACHES TO ASSESSING AND FORECASTING MORBIDITY WITH ENTEROVIRUS (NON-POLIO) INFECTION IN THE RUSSIAN FEDERATION USING MATHEMATICAL MODELS
}

\author{
I.V. Feldblium ${ }^{1}$, V.G. Akimkin², A.V. Alimov ${ }^{3}$, M.V. Piterskiy ${ }^{3}$, Yu.A. Zakharova ${ }^{3}$, \\ Yu.A. Mikhaylenko ${ }^{3}$, N.I. Markovich ${ }^{4}$, A.A. Zakharov ${ }^{5}$
}

${ }^{1}$ Perm State Medical University named after Academician E.A. Wagner, 26 Petropavlovskaya Str., Perm, 614000, Russian Federation

${ }^{2}$ Central Research Institute of Epidemiology, 3a Novogireevskaya Str., Moscow, 111123, Russian Federation

${ }^{3}$ Ekaterinburg Research Institute of Viral Infections of State Research Center of Virology and Biotechnology «Vector», 23 Letnyaya Str., Ekaterinburg, 620030, Russian Federation

${ }^{4}$ Perm Center for Immunoprophylaxis, 224 Ekaterininskaya Str., Perm, 614068, Russian Federation

${ }^{5}$ Mendeleev University of Chemical Technology, 9 Miusskaya Sq., Moscow, 125047, Russian Federation

At present it is impossible to develop epidemiologic surveillance and control over any infection regarding studies on dynamics of morbidity, seasonality and periodicity without using mathematical modeling techniques.

Our research goal was to study regularities in manifestations of epidemic process for enterovirus (non-polio) infection (EVnI) in the Russian Federation over 14 years (2006-2019) using mathematical models (linear, logarithmic, power, and exponential approximation).

An optimal mathematical model was selected using three statistical parameters, namely determination coefficient, Fischer's exact test, and standard error. Periodicity of rises and falls in morbidity was calculated with Fourier one-dimensional spectral analysis. Intra-year dynamics of morbidity with EVnI was estimated basing on monthly spread of the disease cases on the RF territory. Classic seasonal decomposition, Census I technique, was applied to analyze time series of monthly morbidity.

It was determined that EVnI epidemic process was unevenly spread over years in the RF in the examined period of time (2006-2019) and there were two opposite trends in it; the first one lasted from 2006 to 2010 when morbidity was declining and the second was from 2010 to 2019 when it was growing. Having analyzed manifestations of EVnI epidemiologic process in long-term dynamics given its uneven spread as per years, we established that it was advisable to use mathematical models approximated as per separate time periods. Average long-term morbidity with EVnI amounted to $8.09 \%$ o0oo in the RF in 2010-2019 with growth rate being equal to $17.7 \%$. Maximum value was registered in $2017(16.32 \%$ oooo). An unfavorable prediction for further epidemic situation development was revealed for the examined period. The epidemic process was characterized with 4-year periodicity and summer-autumn seasonality with peaks usually occurring in August and September. Rates that characterized intensity of the trends in long-term morbidity dynamics and were calculated with mathematical models differed authentically from those obtained via conventional calculations of average values $(\chi=11.08 ;$ d.f. $=1 ; p=0.0009)$.

Key words: enterovirus (non-polio) infection, non-poliomyelitic enteroviruses, epidemic process, epidemiologic surveillance, mathematical modeling, epidemic situation prediction, seasonality, morbidity dynamics.

(c) Feldblium I.V., Akimkin V.G., Alimov A.V., Piterskiy M.V., Zakharova Yu.A., Mikhaylenko Yu.A., Markovich N.I., Zakharov A.A., 2021

Irina V. Feldblium - Doctor of Medical Sciences, Professor, Head of the Epidemiology and Hygiene Department (e-mail: epidperm@mail.ru; tel.: +7 (342) 218-16-68; ORCID: https://orcid.org/0000-0003-4398-5703).

Vasiliy G. Akimkin - Academician of the Russian Academy of Sciences, Doctor of Medical Sciences, Professor, Director (e-mail: vgakimkin@yandex.ru; tel.: +7 (495) 974-96-46; ORCID: https://orcid.org/0000-0003-4228-9044).

Aleksandr V. Alimov - Doctor of Medical Sciences (e-mail: virus@eniivi.ru; tel.: +7 (343) 261-99-47; ORCID: https://orcid.org/0000-0003-0511-9409).

Mikhail V. Piterskiy - Head of the Urals Federal District AIDS Centre (e-mail: piterskiy_mv@eniivi.ru; tel.: +7 (343) 261-99-47; ORCID: https://orcid.org/0000-0001-5506-2389).

Yuliya A. Zakharova - Doctor of Medical Sciences, Associate Professor, Deputy Director responsible for research work (e-mail: z.y.alexandrovna@mail.ru; tel.: +7 (343) 261-99-47; ORCID: https://orcid.org/0000-0003-3416-0902).

Yuliya A. Mikhaylenko - Scientific Secretary (e-mail: mikhailova ya@eniivi.ru; tel.: +7 (343) 261-99-47; ORCID: https://orcid.org/0000-0003-2361-3734).

Nina I. Markovich - Doctor of Medical Sciences, Head Doctor (e-mail: barhat120140@mail.ru; tel.: +7 (342) 209-27-54; ORCID: https://orcid.org/0000-0002-5596-4611).

Alexandr A. Zakharov - master's student (e-mail: alexander.zakharov.1991@gmail.com; tel.: +7 (499) 978-86-60; ORCID: https://orcid.org/0000-0002-8573-0939). 
Introduction. Enterovirus (non-polio) infection $(\mathrm{EVnI})$ as a global issue is given a lot of attention [1, 2] and many research works by leading foreign and domestic scientists focus on examining it ${ }^{1}[3,4]$. Experience gained worldwide and in Russia as well and accumulated knowledge call for their scientific and rational use to influence the epidemic process efficiently. EVnI is a significant issue due to its high intensity, overall prevalence, high share of outbreaks, contagiousness and lethality [5, 6, 7], high resistance of non-polio enteroviruses (NPEV) in the environment [8], and absence of any specific prevention measures $[9,10]$. In the Russian Federation epidemiologic surveillance over EVnI is regulated by the Sanitary Rules "Prevention of enterovirus (non-polio) infection" 2 and methodical guidelines "Epidemiologic surveillance and prevention of enterovirus (non-polio) infection"3. Two departmental target programs were completed before 2017; at present a target program developed for 2018-2022 is being implemented.

However, dynamics of incidence with EVnI in the RF shows that it still apparently tends to grow. According to some authors, this trend occurs due to a change in dominating virulent NPEV variants [11, 12]; according to others, with incidence being revealed more efficiently due to improved laboratory diagnostics ${ }^{4}[13]$.
Therefore, it becomes more vital in the RF to develop new approaches to examining incidence with EVnI [14-17]. Wide use of mathematical modeling is an apparent and vital task in improvement of epidemiologic surveillance regarding development of its information sub-system $[18,19]$.

Our research goal was to examine basic manifestations of the epidemic process for enterovirus (non-polio) infection in the Russian Federation over 14 years (2006-2019) using mathematical models.

Data and methods. Data for analysis of incidence with EVnI from 2006 to 2019 were taken from the Federal Statistic Report Form No. 1 "Data on infectious and parasitic diseases", submitted monthly; the Federal Statistic Report Form No. 2 "Data on infectious and parasitic diseases", submitted annually ${ }^{5}$.

We used several descriptive and evaluative epidemiologic research techniques in the present work (statistic observation based on examining statistic reports and retrospective epidemiologic analysis). Retrospective epidemiologic analysis involved examining absolute incidence rates among population, intensive incidence rates for enterovirus infection (cases per 100 thousand people), intensity of the epidemic process, and longterm and annual dynamics. We used data

${ }^{1}$ Organizatsiya i provedenie dezinfektsionnykh meropriyatii na razlichnykh ob"ektakh $\mathrm{v}$ period provedeniya massovykh meropriyatii: metodicheskie rekomendatsii [Organizing and implementing disinfection activities at various objects during mass events: Methodical guidelines]. Moscow, Rospotrebnadzor's Federal Center for Hygiene and Epidemiology Publ., 2013, 15 p. (in Russian).

${ }^{2}$ Ob utverzhdenii SP 3.1.2950-11 «Profilaktika enterovirusnoi (nepolio) infektsii» (vmeste s «SP 3.1.2950-11. Sanitarnoepidemiologicheskie pravila...»): Postanovlenie Glavnogo gosudarstvennogo sanitarnogo vracha RF ot 27.07.2011 g. № 106 [On approval of SR 3.1.2950-11 "Prevention of enterovirus (non-polio) infection (together with "SR 3.1.2950-11. Sanitary-epidemiologic rules..."): The Order by the RF Chief Sanitary Inspector issued on July 27, 2011 No. 106]. KonsultantPlus. Available at: http://www. consultant.ru/document/cons_doc_LAW_122282/9fecd9944a61a84b2f22cfa5672a1a1a50e8cb11/ (December 19, 2020) (in Russian).

${ }^{3}$ Epidemiologicheskii nadzor i profilaktika enterovirusnoi (nepolio) infektsii: metodicheskie ukazaniya [Epidemiologic surveillance and prevention of enterovirus (non-polio) infection: Methodical guidelines]. Moscow, Rospotrebnadzor's Federal Center for Hygiene and Epidemiology Publ., 2009, 48 p. (in Russian).

${ }^{4} \mathrm{O}$ sostoyanii sanitarno-epidemiologicheskogo blagopoluchiya naseleniya v Rossiiskoi Federatsii v 2018 godu: Gosudarstvennyi doklad [On sanitary-epidemiologic welfare of the population in the Russian Federation in 2018: The state Report]. Moscow, The Federal Service for Surveillance over Consumer Rights Protection and Human Wellbeing Publ., 2019, 254 p. (in Russian).

${ }^{5} \mathrm{Ob}$ utverzhdenii form federal'nogo statisticheskogo nablyudeniya s ukazaniyami po ikh zapolneniyu dlya organizatsii Federal'noi sluzhboi po nadzoru v sfere zashchity prav potrebitelei i blagopoluchiya cheloveka federal'nogo statisticheskogo nablyudeniya za sanitarnym sostoyaniem sub"ekta Rossiiskoi Federatsii: Prikaz Rosstata ot 29.12.2018 g. № 792 [On approval of federal statistic report forms with guidelines on filling in them for organization of federal statistic surveillance over a sanitary situation in RF regions by the Federal Service for Surveillance over Consumer Rights Protection and Human Wellbeing: The Order by Rosstat issued on December 29, 2018 No. 792]. KonsultantPlus. Available at: http://www.consultant.ru/document/cons_doc_LAW_316110/ (December 19, 2020) (in Russian). 
provided by the Federal State Statistic Service on population numbers to calculate intensive rates; the data were published in the Unified interdepartmental information statistic system (UIISS) ${ }^{6}$.

We applied the least square method to fit coefficients in mathematical models and build up trends. The following approximations were used:

- linear: $y=a \cdot x+b$;

- logarithmic: $y=a \cdot \operatorname{Ln}(x)+b$;

- power: $y=b x^{a}$;

- exponential: $y=b \cdot e^{a \cdot x}$.

An optimal mathematical model was selected using three statistical indicators: determination coefficient, Fischer's test, and standard error for $y$ evaluation.

We took average annual growth rates to estimate intensity of the trends in the epidemic process in long-term dynamics. Since analyzed time series didn't exceed 14 observations (the observation period was 14 years), we used nonparametric statistic methods. Spearmen's correlation coefficient was used to determine occurrence and degree of linear correlation between two data sets. Periodicity of rises and falls in incidence was clearly shown through using periodograms and calculated by using Fourier's one-dimensional spectral analysis. If a correlation is strong (coefficient at a certain sine or cosine), we can conclude there is strict periodicity in data at a relevant frequency. Since sine and cosine functions are independent (or orthogonal), we can arithmetically sum the squares of coefficients for each frequency in order to obtain a required periodogram.

Periodogram values can be interpreted as data dispersion (variance) over a relevant period. Periodogram values (on $y$-axis) are calculated as:

$$
P_{k}=\sin _{-} \operatorname{coefficient}_{k}^{2}+\cos _{\text {-coefficient }}^{2} \cdot \frac{N}{2},
$$

where sin and cos are functions of a cyclic component in a time series; $P_{k}$ is periodogram values at frequency $v_{k}$, and $N$ is an overall length of a series. For better visualization, frequency on $x$-axis is transformed into a period: $T_{k}=1 / v_{k}$. Coefficients were calculated by building up a linear multiple regression model where an observed time series were a dependent variable and independents variables or regressors were represented by sine functions of all possible (discrete) frequencies. Fast Fourier transform turned out to be the most efficient solution to the task.

A year dynamic of incidence with EVnI was estimated based on monthly distribution of the disease cases in the Russian Federation during the observation period from 2013 to 2019 . We applied a procedure stipulated by the Methodical guidelines MR 3.1.2.0118-17.3.1.2 ${ }^{7}$ to calculate epidemic thresholds. Classic seasonal decomposition, or Census I method, was applied to analyze time series. The method is based on an assumption that a time series includes four different components: seasonal (usually given as $S t$ where $t$ means a moment of time), trend (Tt), cyclic (Ct), and irregular one or fluctuation (It). A difference between a cyclic and a seasonal component is that the latter has regular (seasonal) periodicity whereas cyclic factors usually have a longer effect which also changes from cycle to cycle. Within Census I method, a trend and a cyclic component are usually combined into one trend-cyclic component $(T C t)$. Specific functional interrelations between these two components can be quite variable. However, we can spot out two basic ways for them to interact with each other, an additive and a multiplicative one:

- additive model: $\mathrm{Xt}=\mathrm{TCt}+\mathrm{St}+\mathrm{It}$,

- multiplicative model: $X t=T t \cdot C t \cdot S t \cdot I t$, where $X t$ is a value of a time series at a time moment $t$.

${ }^{6}$ Ofitsial'nye statisticheskie pokazateli: sistema vvedena sovmestnym Prikazom Minkomsvyazi Rossii i Rosstata ot 16.11.2011 g. № 318/461 [Official statistical indicators. Introduced by the joint Order by the RF Ministry of Digital Development, Communications and Mass Media of the Russian Federation and Rosstat issued on November 16, 2011 No. 318/461]. UIISS. State Statistics. Available at: https://www.fedstat.ru// (December 19, 2020) (in Russian).

${ }^{7}$ MR 3.1.2.0118-17.3.1.2. Metodika rascheta epidemicheskikh porogov po grippu i ostrym respiratornym virusnym infektsiyam po sub"ektam Rossiiskoi Federatsii: metodicheskie rekomendatsii [MR 3.1.2.0118-17.3.1.2. The procedure for calculating epidemic thresholds for influenza and acute respiratory viral infections as per RF regions: methodical guidelines]. Moscow, The Federal Service for Surveillance over Consumer Rights Protection and Human Wellbeing Publ., 2018, 95 p. (in Russian). 


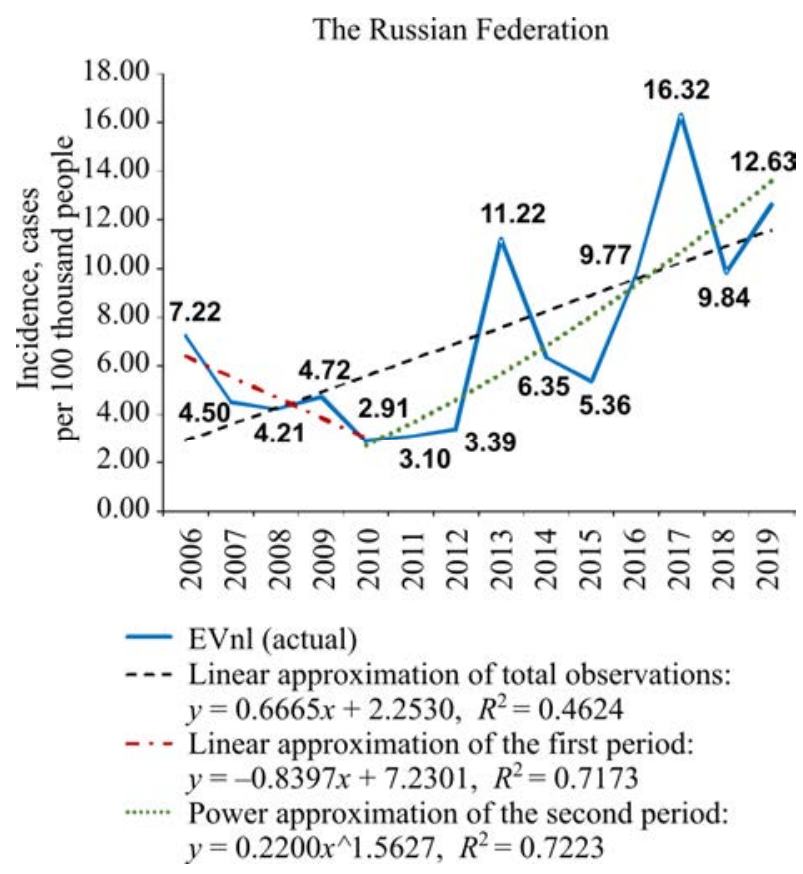

Figure 1. Long-term dynamics of incidence with enterovirus (non-polio) infection in the Russian Federation (2006-2019), cases / 100 thousand people

As for computations, the seasonal decomposition procedure (Census I) complies with the standard formulas [20].

Results and discussion. According to official statistic data, in the RF incidence with EVnI taken over 14 years (2006-2019) was distributed unevenly and tended to grow (Figure 1).

Average annual incidence (AAI) amounted to $7.25 \%$ (standard deviation $=4.1 \%$, 0000 , median $=5.9 \%$, interquartile range varied from $4.28 \%$ o000 to $9.82 \%$, 0000 ), average annual growth rate was $4.4 \%$ (a linear trend slope was $34^{\circ}$ ). Rises in incidence were detected in 2009
(4.72\% \% $(16.32 \%$ o000); each next rise was higher than the previous one. Local minimums were registered in $2010(2.91 \%$ \%000), $2014(6.35 \%$ $2015(5.36 \% 0000)$.

Use of standard epidemiologic approach to estimating incidence for the analyzed period of time indicated that applied mathematical models (linear, logarithmic, power, or exponential approximation) were unsatisfactory for the given time series (Table 1) and that there were at the least two periods with multidirectional trends.

In our opinion, this was due to changes in EVnI cases registration that occurred in 2009 in the RF since Methodical guidelines MU 3.1.1.2363- $08^{8}$ came into force and stipulated the necessity to run laboratory tests to confirm not only group cases but also sporadic ones; this had its influence on quality of EVnI laboratory diagnostics. Given that, we can obtain a relevant mathematical model that determines both a trend and a growth rate for incidence only by dividing a time series into two periods (against the minimal rate in 2010 that was equal to $2.91 \%$ o000). The first period is from 2006 to 2010; the second one, from 2010 to 2019 . We selected a time period from 2010 to 2019 to estimate incidence since it was the most relevant to incidence levels according to power approximation (Table 2).

Given that the observation period was not long enough (only 9 years, 2010-2019), we took median value of incidence that was equal to $6.35 \%$ and interquartile range (IQR) being 3.38-9.84\% $\% 000$ as exponential values in descriptive statistics.

Table 1

Mathematical models applied to analyze dynamics of incidence with enterovirus (non-polio) infection in the Russian Federation (2006-2019)

\begin{tabular}{|l|c|c|c|c|}
\hline \multicolumn{1}{|c|}{ Trend } & Mathematical model & $\begin{array}{c}\text { Determination } \\
\text { coefficient } R^{2}\end{array}$ & F-criterion & $\begin{array}{c}\text { Standard error } \\
\text { for } y \text { evaluation }\end{array}$ \\
\hline Linear approximation & $y=0.6665 x+2.2530$ & 0.4624 & 10.3216 & 3.1292 \\
\hline Logarithmic approximation & $y=2.6436 \mathrm{Ln}(x)+2.4950$ & 0.2491 & 3.9807 & 3.6982 \\
\hline Power approximation & $y=3.5140 x^{0.3228}$ & 0.2027 & 3.0514 & 0.5158 \\
\hline Exponential approximation & $y=3.2716 \mathrm{e}^{0.0870 x}$ & 0.4298 & 9.0461 & 0.4362 \\
\hline
\end{tabular}

${ }^{8}$ MU 3.1.1.2363-08. Epidemiologicheskii nadzor i profilaktika enterovirusnoi (nepolio) infektsii: metodicheskie ukazaniya [MU 3.1.1.2363-08. Epidemiologic surveillance and prevention of enterovirus (non-polio) infection: methodical guidelines]. Moscow, Rospotrebnadzor's Federal Center for Hygiene and Epidemiology Publ., 2009, 48 p. (in Russian). 
Table 2

Mathematical models applied to analyze dynamics of incidence with enterovirus (non-polio) infection in the Russian Federation (2010-2019)

\begin{tabular}{|l|c|c|c|c|}
\hline \multicolumn{1}{|c|}{ Trend } & Mathematical model & $\begin{array}{c}\text { Determination } \\
\text { coefficient } R^{2}\end{array}$ & $F$-criterion & $\begin{array}{c}\text { Standard error } \\
\text { for } y \text { evaluation }\end{array}$ \\
\hline Linear approximation & $y=1.1757 x-3.0816$ & 0.6055 & 12.2809 & 3.0473 \\
\hline Logarithmic approximation & $y=10.4144 \mathrm{Ln}(x)-14.8374$ & 0.6054 & 12.2759 & 3.0477 \\
\hline Power approximation & $y=0.2200 \mathrm{x}^{1.5627}$ & 0.7223 & 20.8058 & 0.3513 \\
\hline Exponential approximation & $y=1.3230 \mathrm{e}^{0.1732 x}$ & 0.6966 & 18.3699 & 0.3671 \\
\hline
\end{tabular}

Analysis of incidence performed by using this approached revealed that average annual incidence with EVnI in the RF amounted to $8.09 \%$ \%000; average annual growth rate, $17.7 \%$ (linear trend slope was $50^{\circ}$ ). According to the power function, EVnI epidemic process developed uncontrollably and forecasts were unfavorable.

Having compared incidence rates for the whole time series (2006-2019) and 2010-2019 time series, we detected statistically significant differences $\left(\chi^{2}=11.08\right.$, d.f. $\left.=1, p=0.0009\right)$ in annual average growth rates (4.4\% against $17.7 \%$ ) and linear trend slopes $\left(34^{\circ}\right.$ against $50^{\circ}$ ).

Fourier's spectral analysis was applied to examine periodicity in the time series of incidence with EVnI; this was done to determine correlations between sine and cosine functions with different frequencies and observed data (Figure 2).

Fourier's spectral analysis of the time series of incidence with $\mathrm{EVnI}$ in the RF given as periodogram

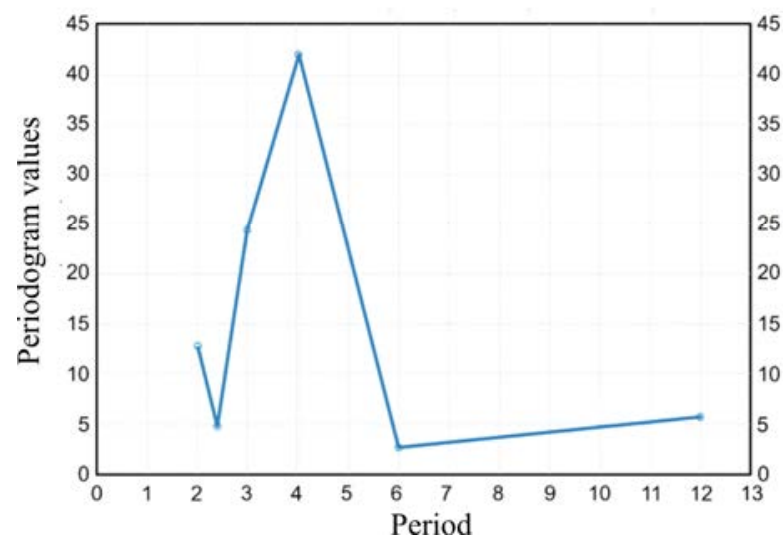

Figure 2. Periodogram showing incidence with enterovirus (non-polio) infection in the Russian

Federation (2009-2019): $O X$ axis shows periodicity in years, $O Y$ axis is data dispersion over a relevant period
Fourier's spectral analysis revealed 4-year periodicity when average long-term incidence with EVnI (2006-2019) was examined. Local minimums followed local maximums with the same 4-year periodicity.

Incidence with EVnI had apparent summer-autumn seasonality (Figure 3 ).

A seasonal rise in incidence began in July each year and ended in November with peaks usually reached in August and September (Figure 4). According to average annual longterm data, $89.5 \%$ cases occurred during these seasonal rises in incidence with EVnI (from July to November). Specific weight of patients who got infected due to influence by seasonal factors amounted to $82.0 \%$.

Fourier's one-dimensional spectral analysis of a time series for monthly incidence revealed apparent 12-month periodicity; this indicated there were no significant shifts in the beginning and the end of an epidemic rise (Figure 5).

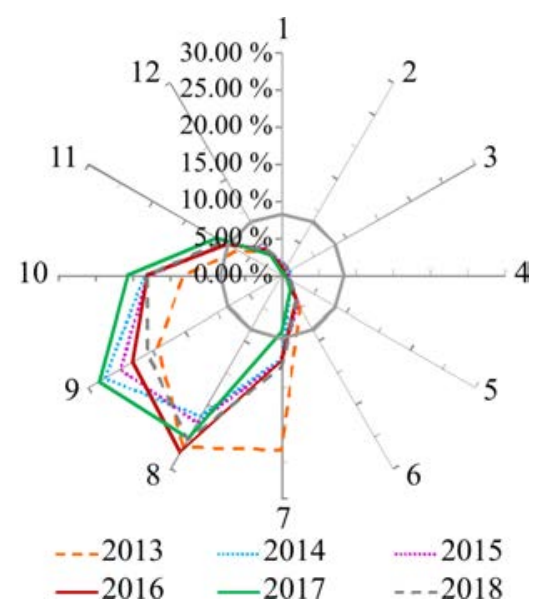

Figure 3. A year dynamics of enterovirus (non-polio) infection in the Russian Federation, shares of total annual incidence (2013-2018, rays of circle graph show months from January (1) to December (12) 


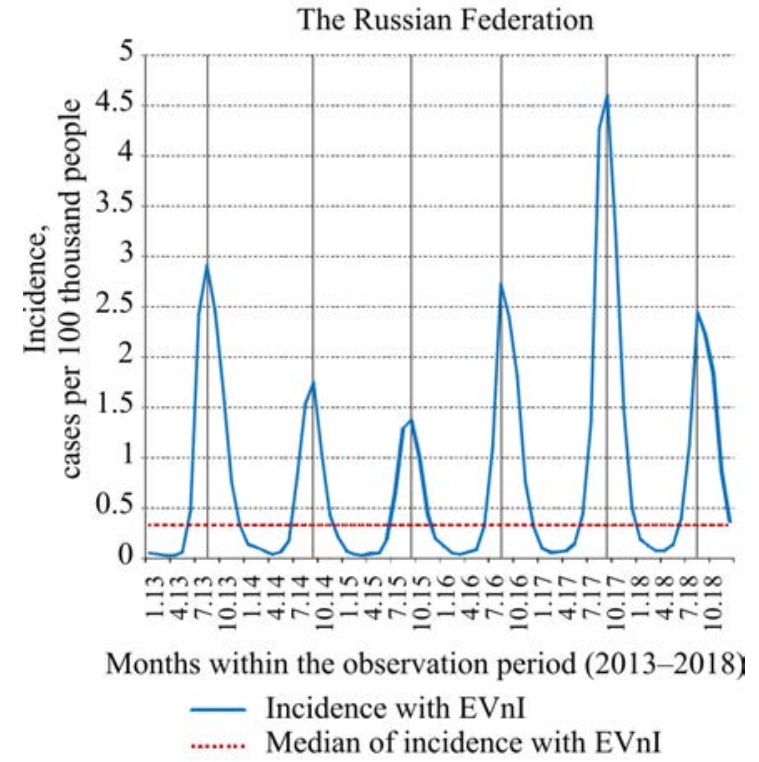

Figure 4. Annual dynamics of incidence with enterovirus (non-polio) infection in the Russian Federation (2013-2018), cases / 100 thousand people

Seasonal component in classical seasonal decomposition of this time series (Census I method) showed annual maximum influence exerted by seasonal factors on incidence growth in July, August, September, and October, both for the additive and multiplicative model (Table 3).

The detected periodicity turned out to be universal regarding the whole time series; however, each year could have individual peculiarities when it came down to the beginning and the end of an epidemic rise. We took retrospective values beyond seasonal epidemic rises in incidence to calculate epidemic thresholds for the analyzed periods. We accomplished primary division of time series as per incidence rate into all-year incidence and seasonal rises; the division was done as per the median for the whole data array. This procedure is widely spread in analyzing time series of incidence and often used by the World Health Organization since the median is not significantly influenced by a peak in incidence, as opposed to other mean values (simple mean, geometric mean, or harmonic mean).

Having calculated upper tolerance limits (Table 4), we established that the epidemic

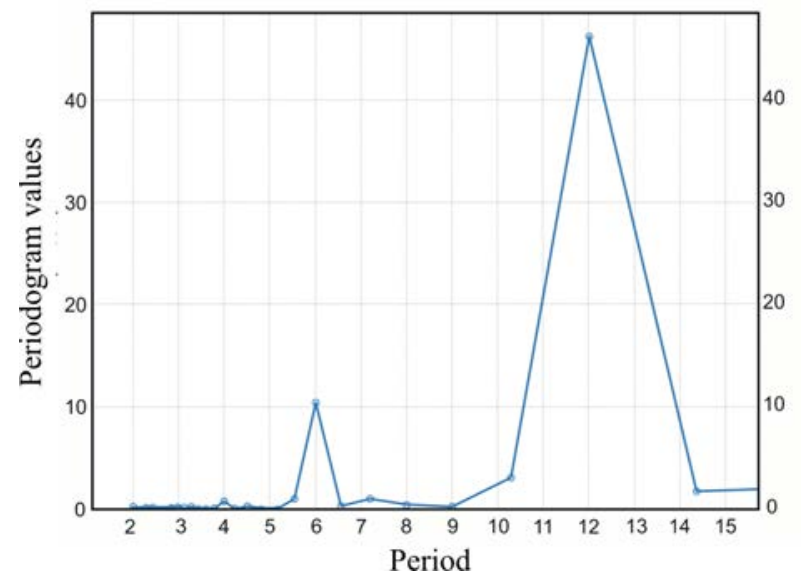

Figure 5. Periodogram showing monthly incidence with enterovirus (non-polio) infection in the Russian Federation (2013-2018): OX axis is periodicity in years, $O Y$ axis is data dispersion over a relevant period

Table 3

Seasonal components in monthly incidence with enterovirus (non-polio) infection in the Russian Federation (2013-2018)

\begin{tabular}{|l|c|c|}
\hline Months & $\begin{array}{c}\text { Seasonal component } \\
\text { for the multiplicative } \\
\text { model }\end{array}$ & $\begin{array}{c}\text { Seasonal component } \\
\text { for the additive } \\
\text { model }\end{array}$ \\
\hline January & 14.5887 & -0.708005977 \\
\hline February & 8.8814 & -0.73590166 \\
\hline March & 6.4100 & -0.746689643 \\
\hline April & 7.4807 & -0.74039556 \\
\hline May & 11.0901 & -0.708328827 \\
\hline June & 39.1541 & -0.498259943 \\
\hline July & $\mathbf{1 4 3 . 0 7 7 3}$ & $\mathbf{0 . 4 1 3 0 9 4 7 5 9}$ \\
\hline August & $\mathbf{3 0 7 . 2 3 7 3}$ & $\mathbf{1 . 7 1 4 4 3 4 1 4}$ \\
\hline September & $\mathbf{3 1 4 . 4 1 7 7}$ & $\mathbf{1 . 6 8 1 7 0 5 3 7}$ \\
\hline October & $\mathbf{2 1 6 . 7 0 9 5}$ & $\mathbf{0 . 9 1 3 2 7 2 9 7 3}$ \\
\hline November & 92.1674 & -0.05959021 \\
\hline December & 38.7857 & -0.525335427 \\
\hline
\end{tabular}

threshold values didn't exceed $0.443 \% 0000$ from January to May. Minimum value was detected in April and amounted to $0.178 \%$ o000. The maximum value was detected in June and amounted to $0.575 \%$. It should be noted that incidence in November was higher than not only the overall median value but also than the maximum epidemic threshold in 4 cases out of 6 . Given that, we concluded that November should be among months of seasonal rises in incidence despite low values of its seasonal component. 
Table 4

Epidemic thresholds of incidence with enterovirus (non-polio) infection calculated as per data on monthly incidence in the Russian Federation in 2013-2018 (cases / 100 thousand people)

\begin{tabular}{|c|c|c|c|c|c|c|c|c|c|}
\hline Month & 2013 & 2014 & 2015 & 2016 & 2017 & 2018 & $\begin{array}{l}\text { Average } \\
\text { monthly } \\
\text { incidence }\end{array}$ & $\begin{array}{c}\text { Upper } \\
\text { tolerance } \\
\text { limit }\end{array}$ & Median \\
\hline January & 0.052 & 0.138 & 0.074 & 0.117 & 0.101 & 0.192 & 0.112 & & 0.10937 \\
\hline February & 0.038 & 0.106 & 0.037 & 0.049 & 0.057 & 0.126 & 0.069 & & 0.05281 \\
\hline March & 0.03 & 0.077 & 0.029 & 0.042 & 0.059 & 0.075 & 0.052 & & 0.05076 \\
\hline April & 0.031 & 0.041 & 0.045 & 0.058 & 0.076 & 0.075 & 0.054 & & 0.052 \\
\hline May & 0.064 & 0.061 & 0.049 & 0.083 & 0.144 & 0.132 & 0.089 & & 0.074 \\
\hline June & 0.476 & 0.173 & 0.192 & 0.327 & 0.443 & 0.394 & 0.334 & & 0.36 \\
\hline July & 2.426 & 0.808 & 0.637 & 1.1 & 1.356 & 1.118 & 1.241 & & 1.109 \\
\hline August & 2.913 & 1.528 & 1.288 & 2.722 & 4.271 & 2.444 & 2.528 & & 2.583 \\
\hline September & 2.449 & 1.744 & 1.374 & 2.4 & 4.598 & 2.222 & 2.465 & & 2.311 \\
\hline October & 1.654 & 1.036 & 1.001 & 1.805 & 3.231 & 1.834 & 1.76 & & 1.729 \\
\hline November & 0.757 & 0.432 & 0.443 & 0.753 & 1.481 & 0.862 & 0.788 & & 0.755 \\
\hline December & 0.33 & 0.21 & 0.193 & 0.312 & 0.498 & 0.361 & 0.317 & & 0.321 \\
\hline \multicolumn{7}{|c|}{ Monthly incidence with threshold as per median for the whole data array: } & \multicolumn{2}{|c|}{$\begin{array}{c}\text { Median } \\
\text { (all months, 2013-2018) }\end{array}$} & 0.328 \\
\hline January & 0.052 & 0.138 & 0.074 & 0.117 & 0.101 & 0.192 & & 0.443 & \\
\hline February & 0.038 & 0.106 & 0.037 & 0.049 & 0.057 & 0.126 & & 0.322 & \\
\hline March & 0.03 & 0.077 & 0.029 & 0.042 & 0.059 & 0.075 & & 0.195 & \\
\hline April & 0.031 & 0.041 & 0.045 & 0.058 & 0.076 & 0.075 & & 0.178 & \\
\hline May & 0.064 & 0.061 & 0.049 & 0.083 & 0.144 & 0.132 & & 0.355 & \\
\hline June & ex & 0.173 & 0.192 & 0.327 & ex & ex & & 0.575 & \\
\hline July & ex & ex & ex & ex & ex & ex & & & \\
\hline August & ex & ex & ex & ex & ex & ex & & & \\
\hline September & ex & ex & ex & ex & ex & ex & & & \\
\hline October & ex & ex & ex & ex & ex & ex & & & \\
\hline November & ex & 0.432 & 0.443 & ex & ex & ex & & & \\
\hline December & ex & 0.21 & 0.193 & 0.312 & ex & ex & & 0.503 & \\
\hline
\end{tabular}

$\mathrm{N}$ o t e : ex means incidence exceeded epidemic threshold in a given month.

Conclusions. Therefore, in the RF incidence with EVnI was characterized with two opposite trends over the examined period (2006-2019): had 4-year periodicity and apparent summer-autumn seasonality (seasonality coefficient was equal to $82 \%$ ). The epidemic process was uncontrollable and forecasts for its development were unfavorable. We analyzed manifestations of EVnI epidemic process in long-term dynamics given its uneven spread over years and established that it was advisable to apply mathematical models approximated as per separate time periods. Average annual long-term incidence taken over the observation period 2010-2019 amounted to $8.09 \%$; 0000 ; average annual growth rate, $17.7 \%$; linear trend slope, $50^{\circ}$. Rates that characterized intensity of the trend in long-term incidence dynamics that were calculated based on mathematical modeling were statistically significantly different from those obtained by calculating mean values $\left(\chi^{2}=11.08\right.$, d.f. $=1, p=0.0009$ ).

Epidemiologic diagnostics of enterovirus infection at the population level can become more qualitative due to wide use of mathematical models in epidemiologic research procedures when estimating manifestations of the epidemic process in long-term dynamics as well as when estimating its spatial characteristics.

Funding. The research was accomplished within implementing Rospotrebnadzor's brunch scientific research program "Problem-oriented scientific research in the sphere of surveillance over infectious and parasitic diseases in 2016-2020" 
and stipulated in the Item 1.5.2. (Register number in the Unified state information system for record of scientific research, development, and technological works is AAAA-A16-116061710036-0) and Item 3.1.11. (register number in the Unified state information system for record of scientific research, development, and technological works is AAAA-A16-116061710033-9) in it.

Conflict of interests. The authors declare there is no any conflict of interests.

\section{References}

1. Lukashev A.N., Ivanova O.E., Khudyakova L.V., Morozova N.S. Sotsial'no-ekonomicheskaya znachimost' enterovirusnoi infektsii i ee rol' v strukture infektsionnoi patologii v mire [Socio-economic significance of enterovirus infection and its role in the structure of infectious pathology in the world]. Zhurnal mikrobiologii, epidemiologii i immunobiologii, 2010, no. 5, pp. 113-120 (in Russian).

2. Briko N.I. Enterovirusnye nepoliomielitnye infektsii [Enteroviral non-polio infections]. Medsestra, 2006, vol. 7, pp. 2-10 (in Russian).

3. Trotsenko O.E., Sapega E.Yu., Butakova L.V. Enterovirus infection: overview of the current global situation in the context of intensified migration flows. Zdorov'e naseleniya i sreda obitaniya, 2018, no. 301, pp. 55-60 (in Russian).

4. Alimov A.V., Igonina E.P., Feldblyum I.V., Chalapa V.I., Zakharova Yu.A. Current status of healthcare-associated enteroviral (non-polio) infections. Infektsiya i immunitet, 2020, vol. 10, no. 3, pp. 486-496 (in Russian).

5. Kanaeva O.I. Enterovirus infection: variety of etiological factors and clinical manifestations. Infektsiya i immunitet, 2014, vol. 4, no. 1, pp. 27-36 (in Russian).

6. Thorén A., Widell A. PCR for the Diagnosis of Enteroviral Meningitis. Scandinavian Journal of Infectious Diseases, 1994, vol. 26, no. 3, pp. 249-254. DOI: 10.3109/00365549409011792

7. Voroshilova M.K. Enterovirusnye infekcii cheloveka [Human enterovirus infections]. Moscow, Meditsina, 1979, 360 p. (in Russian).

8. Harvala H., Broberg E., Benschop K., Berginc N., Ladhani S., Susi P., Christiansen C., McKenna J. [et al.]. Recommendations for enterovirus diagnostics and characterization within and beyond Europe. Journal of Clinical Virology, 2018, vol. 101, pp. 11-17. DOI: 10.1016/j.jcv.2018.01.008

9. Yagovkin E.A., Onishchenko G.G., Popova A.Yu., Ezhlova E.B., Melnikova A.A., Soloviev M.Yu., Kovalev E.V., Tverdokhlebova T.I. [et al.]. Condition and prospects of development of vaccines for specific prevention of enterovirus (nonpolio) infection. Epidemiologiya i vaktsinoprofilaktika, 2016, vol. 15, no. 4, pp. 74-82 (in Russian).

10. Shestopalov N.V., Akimkin V.G. Sovershenstvovanie dezinfektsionnykh i sterilizatsionnykh meropriyatii $\mathrm{v}$ sisteme mer nespetsificheskoi profilaktiki ISMP [Improvement of disinfection and sterilization measures in the system of measures for non-specific prevention of HAI]. Poliklinika, 2014, no. 6, p. 21 (in Russian).

11. Romanenkova N.I., Golitsyna L.N., Bichurina M.A., Rozaeva N.R., Kanaeva O.I., Zverev V.V., Sozonov D.V., Cherkasskaya I.V. [et al.]. Enterovirus infection morbidity and peculiarities of nonpolio enteroviruses circulation on some territories of Russia in 2017. Zhurnal infektologii, 2018, vol. 10, no. 4, pp. 124-133. DOI: 10.22625/2072-6732-2018-10-4-124-133 (in Russian).

12. Sergeev A.G., Ustyuzhanin A.V., Rezaikin A.V., Alimov A.V. Assessment of the epidemiological risk strains of non-polio enteroviruses circulating among the population, the results of molecular-genetic. Dal'nevostochnyi zhurnal infektsionnoi patologii, 2015, no. 28, pp. 20-26 (in Russian).

13. Golitsyna L.N., Zverev V.V., Selivanova S.G., Ponomareva N.V., Kashnikov A.Yu., Sozonov D.V., Sashina T.A., Epifanova N.V. [et al.]. Etiological structure of enterovirus infections in the Russian Federation in 2017-2018. Zdorov'e naseleniya i sreda obitaniya, 2019, no. 8, pp. 30-38 (in Russian). DOI: 10.35627/2219-5238/2019-317-8-30-38

14. Zmeeva T.A., Malyshev V.V. Modern membrane technology sample preparation and detection of viral contamination of water objects of the environment. Vestnik Rossiiskoi voenno-meditsinskoi akademii, 2018, no. S1, pp. 67-70 (in Russian).

15. Bailly J.L., Mirand A., Henquell C., Archimbaud C., Chambon M., Charbonné F., Traoré O., Peigue-Lafeuille H. Phylogeography of circulating populations of human echovirus 30 over 50 years: 
Nucleotide polymorphism and signature of purifying selection in the VP1 capsid protein gene. Infection, Genetics and Evolution, 2009, vol. 9, no. 4, pp. 699-708. DOI: 10.1016/j.meegid.2008.04.009

16. Chambon M., Bailly J.L., Béguet A., Henquell C., Archimbaud C., Gaulme J., Labbé A., Malpuech G., Peigue-Lafeuille H. An outbreak due to Echovirus type 30 in a neonatal unit in France in 1997: Usefulness of PCR diagnosis. Journal of Hospital Infection, 1999, vol. 43, no. 1, pp. 63-68. DOI: $10.1053 /$ jhin. 1999.0634

17. Gaunt E., Harvala H., Österback R., Sreenu V.B., Thomson E., Waris M., Simmonds P. Genetic characterization of human coxsackievirus A6 variants associated with atypical hand, foot and mouth disease: a potential role of recombination in emergence and pathogenicity. The Journal of general virology, 2015, vol. 96, no. Pt 5, pp. 1067-1079. DOI: 10.1099/vir.0.000062

18. Laiho J.E., Oikarinen S., Oikarinen M., Larsson P.G., Stone V.M., Hober D., Oberste S., Flodström-Tullberg M. [et al.]. Application of bioinformatics in probe design enables detection of enteroviruses on different taxonomic levels by advanced in situ hybridization technology. Journal of Clinical Virology, 2015, vol. 69, pp. 165-171. DOI: 10.1016/j.jcv.2015.06.085

19. Rames E., Macdonald J. Evaluation of MinION nanopore sequencing for rapid enterovirus genotyping. Virus Research, 2018, vol. 252, pp. 8-12. DOI: 10.1016/j.virusres.2018.05.010

20. Makridakis S., Wheelwright S.C., McGee V.E. Metode dan aplikasi peramalan [Forecasting methods and applications]. Jakarta, Erlangga, 1999, 540 p. (in Indonesian).

Feldblium I.V., Akimkin V.G., Alimov A.V., Piterskiy M.V., Zakharova Yu.A., Mikhaylenko Yu.A., Markovich N.I., Zakharov A.A. New approaches to assessing and forecasting morbidity with enterovirus (non-polio) infection in the Russian Federation using mathematical models. Health Risk Analysis, 2021, no. 3, pp. 107-115. DOI: 10.21668/health.risk/2021.3.10.eng

Received: 01.06.2021

Accepted: 17.08 .2021

Published: 30.09.2021 